\title{
NAA Lebih Efektif Dibanding IBA untuk Pembentukan Akar pada Cangkok Jambu Bol (Syzygium malaccense (L.) Merr \& Perry)
}

\author{
NAA Was More Effective Than IBA in Root Formation of Malay Apple \\ (Syzygium malaccense (L.) Merr \& Perry) Airlayers
}

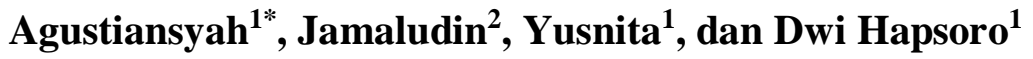

Diterima 24 Mei 2017/Disetujui 8 Januari 2018

\begin{abstract}
A study to determine the effect of auxin talcum on rooting of air layered malay apple (Syzygium malaccense (L.) Merr. \& Perry) was conducted from March to May 2016. The experiment was arranged in a randomized complete block design with three replications, five branches per experimental unit. Auxin talcum treatment consisting of 7 level of auxin concentrations, i.e., (in ppm) $O$ (control), 2000 IBA, 4000 IBA, 2000 NAA, 4000 NAA, 1000 NAA + IBA 1000 and 2000 IBA + 2000 NAA in the form of talcum-paste were applied in the upper region of the girdled branches prior to being covered with soil medium. The results showed that after two months, all treatments containing NAA, either singly or in combination with IBA produced $100 \%$ rooting, whereas the control treatment was only 22\%. The IBA treatments singly at 2000 and 4000 ppm produced $44.4 \%$ and 55.6\% rooting, respectively. The superiority of NAA upon IBA treatments was also shown by the higher number and length of primary roots as well as earlier root formation. The best treatment for Malay apple rooting was 4000 ppm NAA which produced 33.3 roots, and formed roots three weeks earlier than the control treatment.
\end{abstract}

Key words: air layering, auxin, IBA, NAA, rooting

\begin{abstract}
ABSTRAK
Penelitian ini bertujuan mempelajari pengaruh formulasi pasta auksin yang mengandung IBA, NAA atau kombinasi keduanya terhadap pengakaran cangkok jambu bol (Syzygium malaccense L.) Merr. \& Perry). Percobaan dilaksanakan dari bulan Maret sampai Mei 2016 menggunakan rancangan acak kelompok dengan tiga ulangan, 5 cabang cangkokan per unit percobaan. Perlakuan terdiri atas 7 taraf konsentrasi auksin (dalam ppm) yaitu 0 (kontrol), 2000 IBA, 4000 IBA, 2000 NAA, 4000 NAA, $1000 \mathrm{NAA}+$ IBA 1000 dan 2000 IBA + 2000 NAA. Hasil pengamatan pada dua bulan setelah perlakuan, semua perlakuan yang mengandung NAA, baik secara tunggal maupun dalam kombinasi dengan IBA menghasilkan $100 \%$ cangkok berakar, sementara kontrol hanya menghasilkan $22 \%$, dan perlakuan IBA saja pada 2000 dan 4000 ppm menghasilkan $44.4 \%$ and $55.6 \%$ cangkok berakar. NAA yang lebih tinggi dibandingkan IBA juga ditunjukkan oleh lebih tingginya jumlah akar, panjang akar dan waktu terbentuknya akar yang lebih awal dibandingkan kontrol. Perlakuan auksin terbaik didapatkan pada 4000 ppm NAA yang menghasilkan 33.3 akar primer dan mempercepat terbentuknya akar hingga tiga minggu lebih awal dibandingkan dengan pada cangkok tanpa auksin.
\end{abstract}

Kata kunci: auksin, cangkok, IBA, NAA, pengakaran 


\section{PENDAHULUAN}

Jambu bol (Syzygium malaccense L.) Merr \& Perry (sinonim: Eugenia malaccensis L.) merupakan salah satu tanaman buah anggota famili Myrtaceae yang berasal dari Asia Tenggara, dan termasuk spesies tanaman asli Indonesia. Jambu bol mempunyai nama-nama daerah lain, yaitu jambu bol (Indonesia), otaheite cashew (Jamaica) atau Malay apple (Inggris). Pohon jambu bol mempunyai tajuk berbentuk piramid atau silindris, tingginya dapat mencapai $20 \mathrm{~m}$, memiliki cabang horisontal yang banyak dan berpotensi menghasilkan buah 21-85 kg per pohon (Whistler dan Elevitch, 2006; Blench, 2008; Orwa et al., 2009). Nilai gizi yang terkandung dalam buah jambu bol yang masak cukup tinggi, yaitu dalam setiap $100 \mathrm{~g}$ buah segar terkandung 0.5-0.7 g protein, 0.6-0.8 g serat, 5.6-69 mg kalsium, 3-10 I.U vitamin A dan 6.5-17 mg vitamin C. Bagian lain tanaman ini seperti daun dan kulit dapat digunakan sebagai obat tradisional untuk beberapa penyakit seperti sakit perut, gatal, penurun suhu tubuh, hingga penyakit diabetes.

Perbanyakan jambu bol dengan biji mempunyai beberapa kendala, yaitu karakter buah yang dihasilkan belum tentu sama dengan karakter tanaman induknya, masa juvenil tanaman yang lama (5 tahun atau lebih) dan dalam satu buah jambu bol yang besar umumnya hanya dihasilkan satu atau dua biji, bahkan tidak semua buah jambu bol menghasilkan biji. Di samping itu, biji jambu bol cepat kehilangan viabilitas benihnya (Whistler dan Elvevitch, 2006; Orwa et al., 2009).

Cangkok merupakan teknik perbanyakan vegetatif yang mudah, murah dan relatif efisien untuk menghasilkan bibit jambu bol unggul, karena dapat menghasilkan bibit true-to-type dan dapat memangkas fase juvenil tanaman sehingga bibit yang dihasilkan lebih cepat berproduksi. Namun demikian, beberapa tanaman anggota Myrtaceae seperti Syzygium javanica dan jambu biji (Psidium guajava L.) telah dilaporkan sebagai tanaman yang sulit berakar dengan persentase berakar hanya 20-30\% ketika dicangkok atau disetek tanpa menggunakan zat perangsang akar (Paul dan Aditi, 2009; Sardoei, 2014; Yusnita, et al., 2018). Keberhasilan pengakaran pada cangkok atau setek dipengaruhi oleh banyak faktor yang mungkin saling berinteraksi satu sama lain, di antaranya ialah faktor genotipe (Zaczek et al., 2006; Denaxa et al., 2011), umur fisiologi bahan tanaman (Santoso, 2014), umur ontogenetik tanaman (Zaczek et al., 2006), musim, temperatur, fotoperiodisitas (Singh et al., 2011), media pengakaran yang digunakan (Shadparvar et al., 2011; Ansari, 2013; Benti, 2014; Rahmania dan Kurniawati, 2014), ukuran bahan perbanyakan (Rahmania dan Kurniawati, 2014; Apriani dan Suhartanto, 2015), dan zat pengatur tumbuh (ZPT). Zat Pengatur Tumbuh, terutama dari golongan auksin merupakan salah satu faktor penentu dalam keberhasilan pengakaran pada cangkok berbagai tanaman yang sulit berakar (Dirr dan Junior, 2006; Hartmann et al., 2011). Namun, efektifitas ZPT untuk merangsang pembentukan akar tergantung pada jenis, konsentrasinya, serta spesies tanaman yang diakarkan.

ZPT auksin yang saat ini paling banyak digunakan untuk menginduksi akar pada setek atau cangkok ialah indole-3-butyric acid (IBA), dan $\alpha$-napthalene-acetic acid (NAA). Auksin juga dapat menghambat pertumbuhan tunas, dan pada konsentrasi tinggi dapat berefek herbisida (Blythe et al., 2007). IBA dan NAA dapat diaplikasikan baik secara tunggal atau dikombinasikan untuk mendapatkan efek pengakaran pada cangkok secara aditif atau sinergistik (Dessalegn dan Reddy, 2003). Pada setek tanaman zaitun, IBA pada konsentrasi 3000 ppm merupakan konsentrasi terbaik untuk menghasilkan persentase setek berakar, jumlah akar, panjang tunas, berat kering dan rasio antara akar dan tunas tertinggi (Khajehpour et al., 2014). Rebin (2013) mendapatkan bahwa IBA pada konsentrasi 500 ppm terbukti efektif merangsang pengakaran setek jambu citra. Yan et al. (2014), melaporkan bahwa konsentrasi NAA 200 ppm menghasilkan persentase setek berakar, jumlah dan bobot akar tertinggi pada setek rumput pakan ternak Hemarthria compressa.

Penelitian mengenai pengaruh auksin terhadap pengakaran pada cangkok jambu bol sejauh ini belum dilaporkan, namun pada penyetekan jambu bol, Ryadin et al. (2004), mendapatkan bahwa aplikasi IAA atau NAA pada konsentrasi 1000 ppm, masing-masing dapat merangsang pembentukan akar. Pada penelitian tersebut NAA dilaporkan lebih efektif dibanding IAA, namun tidak dijelaskan berapa persen keberhasilan penyetekannya. Penelitian ini bertujuan mengetahui pengaruh NAA, IBA, dan kombinasinya terhadap pengakaran pada cangkok jambu bol. 


\section{BAHAN DAN METODE}

Percobaan dilaksanakan di Desa Banjar Rejo, Kecamatan Batang Hari, Kabupaten Lampung Timur dari bulan Februari sampai April 2016. Percobaan ini dilakukan dengan menggunakan rancangan acak kelompok lengkap (randomized complete block design) dengan tiga kelompok berdasarkan pohon induk yang dicangkok. Perlakuan yang dicobakan adalah tujuh konsentrasi auksin yang terdiri atas kontrol (tanpa auksin), IBA 2000 ppm, IBA 4000 ppm, NAA 2000 ppm, NAA 4000 ppm, IBA $1000 \mathrm{ppm}$ + NAA $1000 \mathrm{ppm}$, dan IBA 2000 ppm + NAA 2000 ppm.

Bahan tanaman yang akan dicangkok dipilih pohon induk jambu bol yang sudah pernah berbuah, dengan pertumbuhan yang sehat dan kuat, dan berumur 8-10 tahun. Cabang yang akan dicangkok dipilih dari cabang sekunder yang sehat pertumbuhannya, pada posisi $\pm 50 \mathrm{~cm}$ dari ujung cabang berdiameter $\pm 1.5-2.0 \mathrm{~cm}$. Media yang digunakan untuk pengakaran cangkok ialah campuran antara tanah dengan kompos dengan perbandingan 1:1 (v/v) yang dibungkus dengan plastik bening/ transparan. NAA dan IBA yang digunakan merupakan auksin murni. Auksin tersebut dicampur dengan talk dengan perbandingan sesuai konsentrasi yang akan dicoba. Pada saat akan diaplikasikan campuran auksin dan talk tersebut ditambahkan air secukupnya sehingga menjadi bentuk pasta, diaplikasikan dengan cara dioleskan pada cabang terpilih.

Pengamatan dilakukan pada umur 2 bulan setelah pencangkokan, untuk variabel persentase cangkok yang berakar, rata-rata jumlah akar, dan rata-rata panjang akar dengan membongkar media tanam. Pengamatan waktu munculnya akar hanya dilakukan untuk perlakuan kontrol, 4000 ppm NAA, dan 4000 ppm IBA. Pengamatan dilakukan setiap minggu dimulai dari akhir minggu pertama hingga minggu ke-8 dengan mengamati akar yang telah menembus media cangkok.

\section{HASIL DAN PEMBAHASAN}

\section{Persentase Cangkok Berakar}

Hasil percobaan menunjukkan bahwa semua jenis dan konsentrasi auksin yang dicobakan pada cangkok jambu bol meningkatkan persentase cangkok berakar, namun NAA dan IBA + NAA jauh lebih efektif dibanding IBA. Pada Gambar 1 dapat lihat bahwa kontrol (tanpa auksin), persentase cangkok jambu bol yang berakar hanya $22.2 \%$. Aplikasi 2000 dan 4000 ppm IBA menghasilkan berturut-turut persentase cangkok berakar $44.4 \%$ dan $55.6 \%$, sedangkan aplikasi 2000 dan 4000 ppm NAA maupun kombinasi IBA + NAA dengan total konsentrasi yang sama semuanya menghasilkan persentase cangkok 100\% (Gambar 1). Hasil penelitian ini membuktikan bahwa jambu bol yang merupakan salah satu anggota famili Myrtaceae termasuk spesies yang sulit berakar, karena tanpa aplikasi auksin, persen berakar cangkok sangat rendah, yaitu hanya $22.2 \%$. Hasil tersebut konsisten dengan yang didapatkan oleh Paul dan Aditi (2009), yaitu bahwa cangkok jambu air (Syzygium javanica L.) hanya berakar $30 \%$ tanpa aplikasi auksin, sedangkan aplikasi IBA 1000 ppm dan NAA 1000 ppm menghasilkan persentase cangkok berakar berturut-turut sebesar $75 \%$ dan $62.5 \%$. Pada cangkok jambu air tersebut, NAA juga lebih efektif dibanding dengan IBA untuk pembentukan akar. Chawla et al. (2012), melaporkan bahwa pada cangkok Litchi chinensis Sonn., aplikasi IBA 5000 ppm meningkatkan persentase berakar dari $60.3 \%$ tanpa auksin menjadi $86 \%$.

\section{Jumlah Akar Primer}

Hasil percobaan menunjukkan bahwa aplikasi NAA atau kombinasi NAA + IBA secara signifikan meningkatkan jumlah akar primer pada cangkok jambu bol, sedangkan pemberian IBA saja tidak berpengaruh. Cangkok tanpa auksin atau dengan perlakuan IBA 2000 dan 4000 ppm menghasilkan ratarata jumlah akar yang tidak berbeda, yaitu pada kisaran 2.3-4.7. Pemberian NAA 2000 ppm meningkatkan jumlah akar menjadi 16.1 dan jika NAA ditingkatkan menjadi 4000 ppm, jumlah akar meningkat lagi menjadi paling banyak, yaitu 33.3. Selanjutnya, pemberian kombinasi IBA 1000 ppm + NAA 1000 ppm menghasilkan rata-rata 11.1 akar, sedangkan perlakuan 2000 ppm IBA + 2000 ppm NAA menghasilkan 20.1 akar (Gambar 2). 


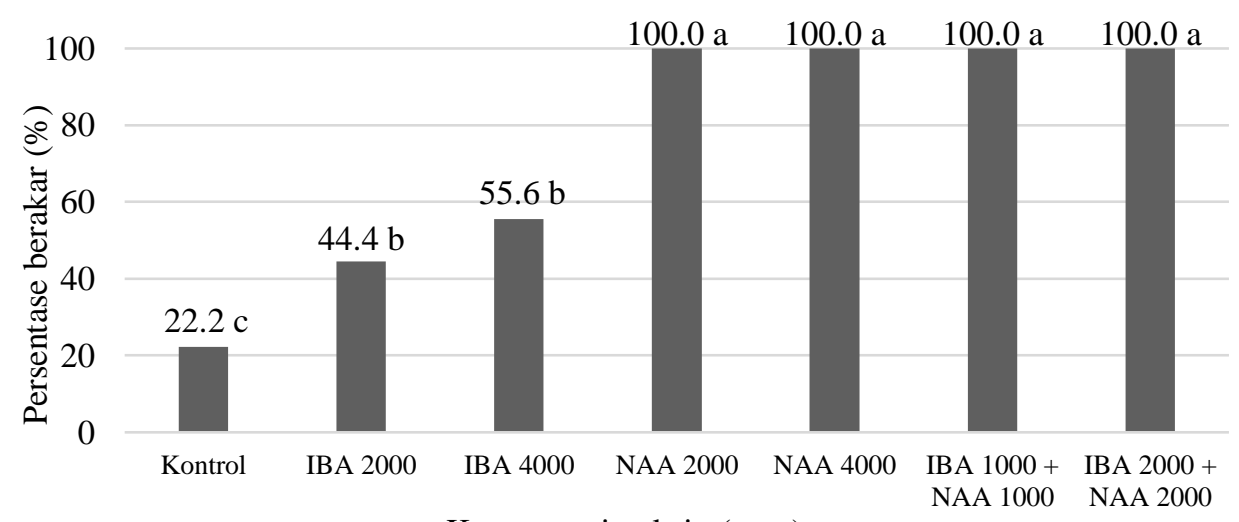

Konsentrasi auksin (ppm)

Gambar 1. Persentase berakar pada cangkok jambu bol pada perlakuan pasta IBA, NAA, dan campuran keduanya pada 8 minggu setelah aplikasi.

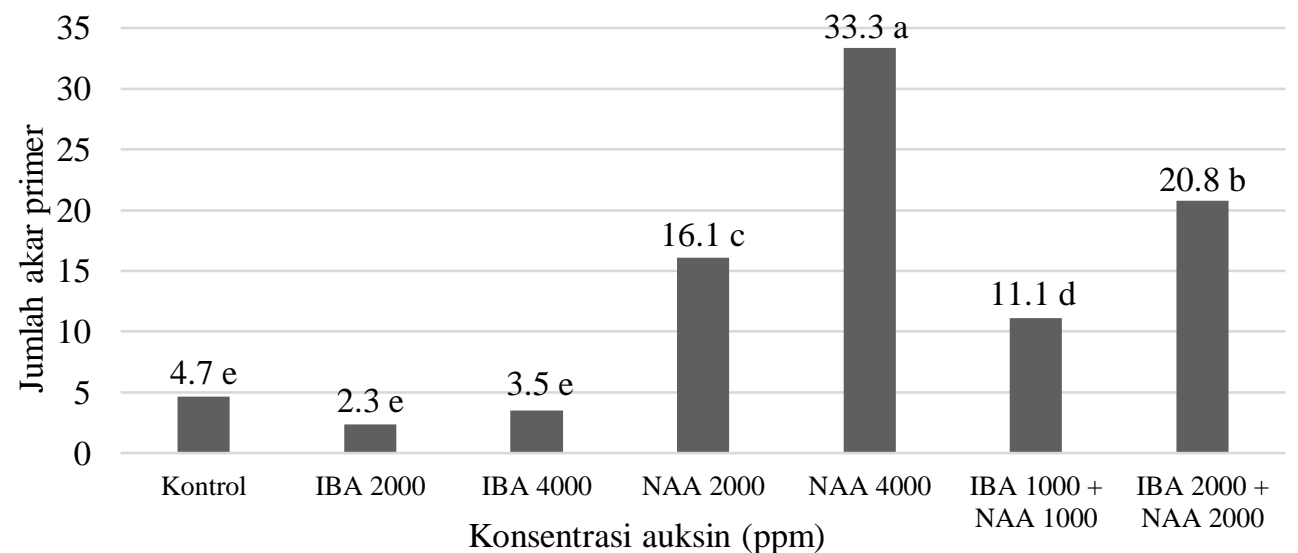

Gambar 2. Rata-rata jumlah akar primer pada cangkok jambu bol setelah diaplikasikan dengan IBA, NAA, dan kombinasi keduanya, 8 minggu setelah aplikasi.

Hasil ini menunjukkan bahwa NAA lebih efektif merangsang inisisasi akar pada cangkok jambu bol dibandingkan dengan IBA, dan peningkatan konsentrasinya dari 1000 , 2000 hingga 4000 ppm menghasilkan jumlah akar yang terus meningkat, sedangkan IBA tidak efektif untuk merangsang pembentukan akar. Pada Gambar 2 terlihat bahwa pemberian IBA dan NAA secara bersama-sama menghasilkan respon akar lebih aditif, dengan efek NAA yang lebih efektif dibanding IBA. Hal ini terlihat pada perlakuan IBA 1000 ppm + NAA 1000 ppm yang menghasilkan 11.1 akar. Jumlah akar yang dihasilkan ini lebih banyak dibanding kontrol, namun masih lebih sedikit daripada yang dihasilkan oleh 2000 ppm NAA (16.1), sedangkan pemberian IBA 2000 + NAA 2000 ppm menghasilkan 20.8 akar. Jumlah akar tersebut lebih banyak dibanding yang dihasilkan oleh 2000 ppm NAA, namun lebih sedikit dibanding dengan yang dihasilkan oleh 4000 ppm NAA (33.1).
Hasil penelitian ini sejalan dengan yang dilaporkan oleh Ryadin et al. (2014), yaitu bahwa NAA lebih efektif untuk pengakaran pada setek jambu bol dibandingkan dengan IBA. Abu-Zahra et al. (2013) mendapatkan bahwa konsentrasi NAA terbaik untuk pengakaran setek berbagai tanaman hias berbeda-beda, yaitu untuk setek Syngonium 1000 ppm, rosemary dan Hedera helix 3000 ppm, dan Gardenia 4000 ppm.

Pengaruh stimulasi NAA dalam menginduksi akar kemungkinan berkaitan dengan penghambatan aktivitas enzim IAAoksidase (IAAO), serta peningkatan aktivitas enzim peroksidase (POD) dan polifenol oksidase (PPO) sebagaimana dilaporkan oleh Yan et al. (2014), pada pengakaran setek Hemarthria compressa yang diberi NAA. Enzim IAAO mengkatalisis oksidasi IAA sehingga mengganggu kerja auksin (Hartmann et al., 2011). Jadi jika IAAO terhambat aktivitasnya oleh NAA, maka kerja auksin endogen lebih 
efektif. Aktivitas POD diketahui berperan dalam metabolisme auksin dan proses lignifikasi pada waktu sintesis dinding sel yang terjadi selama pembentukan akar (Rout, 2006). Selain itu, PPO mengkatalisis oksidasi senyawa polifenol dan hidroksilasi senyawa monophenol serta terbentuknya lignin dalam sel tumbuhan (Khorsheduzzaman et al., 2010).

\section{Panjang Akar}

Cangkok jambu bol tanpa pemberian auksin tidak hanya menghasilkan persentase pengakaran yang rendah (22.2\%) dan jumlah akar yang sedikit (4.7), namun juga menghasilkan rata-rata panjang akar paling kecil, yaitu $1.0 \mathrm{~cm}$. Pemberian IBA secara tunggal pada konsentrasi 2000 dan 4000 ppm tidak mempengaruhi jumlah akar yang terbentuk, namun meningkatkan panjang akar menjadi yang tertinggi yaitu 9.8 dan $11.1 \mathrm{~cm}$. Pemberian NAA 2000 dan 4000 ppm, kombinasi NAA 1000 ppm + IBA 1000 ppm, dan NAA 2000 ppm + IBA 2000 ppm juga meningkatkan rata-rata panjang akar secara signifikan menjadi 5.2-7.4 cm (Gambar 3). Representasi massa akar yang terbentuk pada cangkok jambu bol pada perlakuan NAA disajikan pada Gambar 4, yang menunjukkan bahwa perlakuan NAA pada semua level baik secara sendiri maupun yang dikombinasikan dengan IBA menghasilkan massa akar yang lebih banyak dibanding kontrol, sedangkan IBA menghasilkan massa akar yang lebih sedikit.

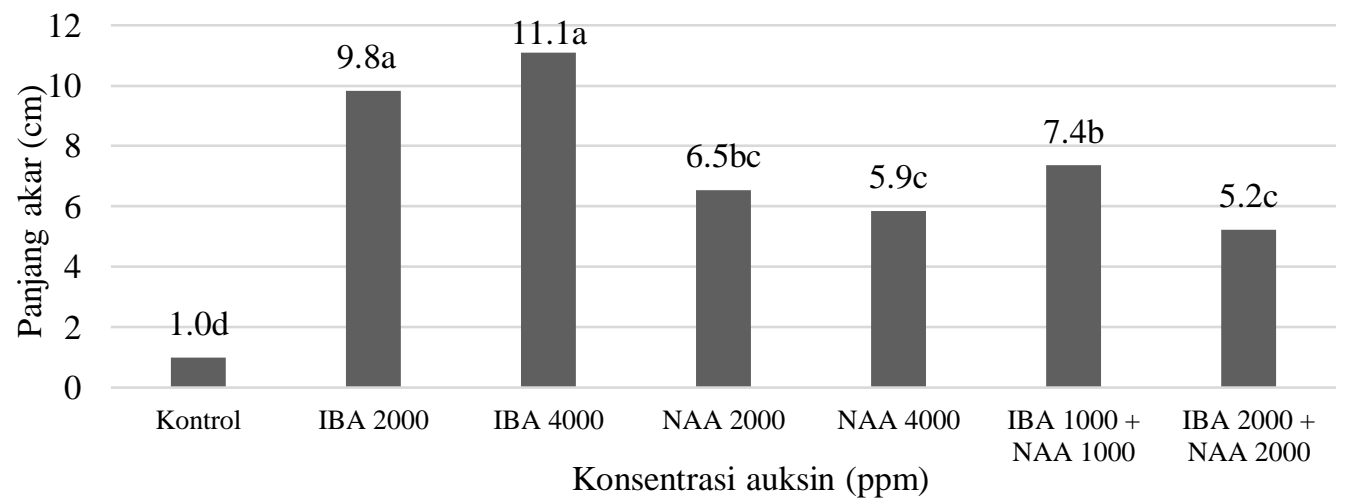

Gambar 3. Rata-rata panjang akar pada cangkok jambu bol setelah diaplikasikan dengan IBA, NAA, dan campuran keduanya, 8 minggu setelah aplikasi.
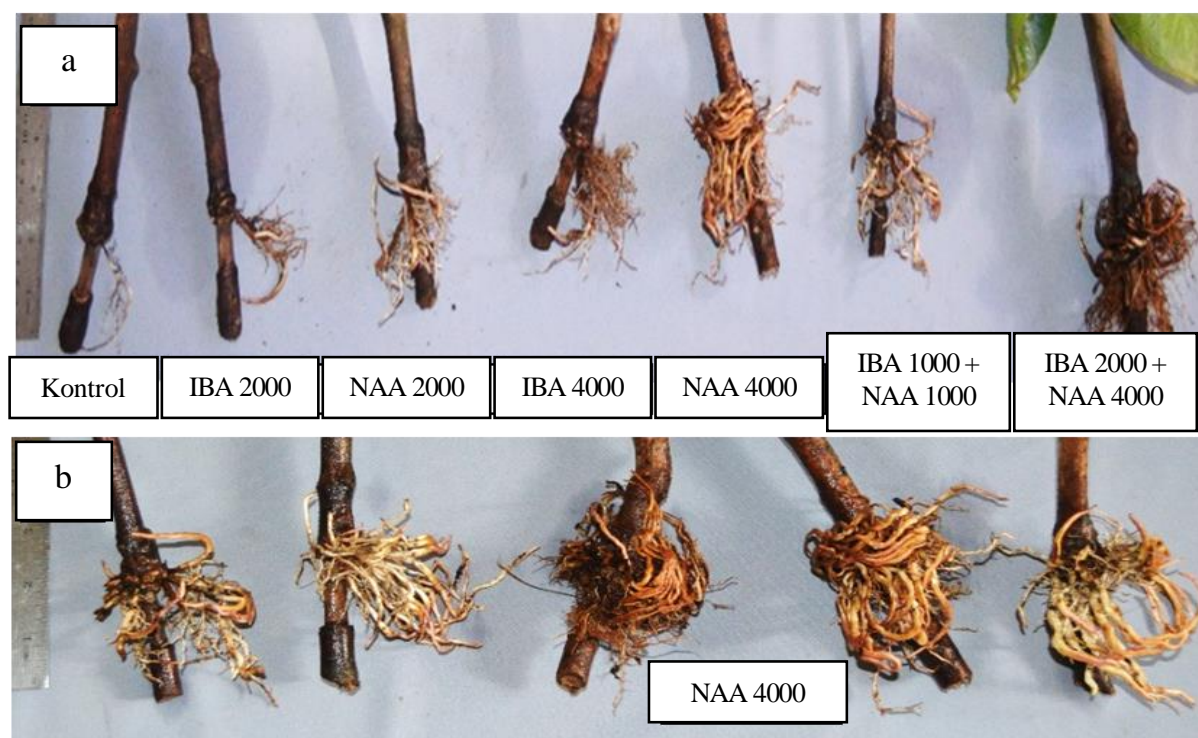

Gambar 4. Penampilan massa akar pada cangkok jambu bol yang diinduksi dengan NAA, IBA dan kombinasinya 8 minggu setelah aplikasi (a); dan massa akar pada semua cangkok yang diberi 4000 ppm NAA (b). 


\section{Waktu Muncul Akar}

Efektivitas NAA yang lebih tinggi dibanding IBA untuk merangsang pengakaran pada cangkok jambu bol tidak hanya terlihat dari jumlah akar primer yang terbentuk, namun juga pada kecepatan waktu munculnya akar. Pada Gambar 5 terlihat bahwa aplikasi auksin yaitu 4000 ppm NAA tidak hanya menghasilkan persentase cangkok berakar yang lebih besar dibanding kontrol pada minggu ke-8, namun juga mempercepat terbentuknya akar. Pada perlakuan kontrol, akar mulai muncul pada minggu ke-6 dengan persentase yang amat rendah, yaitu $6.7 \%$ dan hingga minggu ke- 8 hanya mencapai $33.3 \%$, sedangkan pada perlakuan 4000 ppm NAA munculnya akar mulai teramati pada minggu ke-3 yaitu sebesar $6.7 \%$ lalu meningkat menjadi $73.3 \%$ pada minggu ke-4 dan pada minggu ke-5 sudah mencapai $100 \%$.

Berdasarkan waktu munculnya akar, 4000 ppm NAA lebih efektif dibanding 4000 ppm IBA. Hal tersebut kemungkinan karena kandungan auksin endogen pada cabang jambu bol yang dicangkok terlalu sedikit. Ketika bagian atas cabang yang dikerat dan dikupas floemnya diberi perlakuan NAA pada konsentrasi 4000 ppm, kemungkinan auksin endogen (IAA) pada cangkok dapat ditingkatkan pada level yang lebih tinggi dibandingkan dengan efek yang ditimbulkan oleh IBA pada konsentrasi yang sama, sehingga akar lebih cepat terbentuk. Proses pembentukan akar pada cangkok secara fisiologi dan anatomi hampir sama dengan pada setek batang.

Menurut Hartmann et al. (2011), pembentukan akar adventif pada setek batang terdiri atas dua tahap yaitu tahap inisiasi akar (pembentukan bakal akar) dan tahap pemanjangan primordia akar. Tahap inisiasi akar dapat dibagi menjadi tahap auksin-aktif yang berlangsung sekitar 4 hari, yang mana ketersediaan auksin secara terus menerus esensial untuk pembentukan bakal akar. Setelah bakal akar terbentuk, tahap berikutnya adalah tahap auksin inaktif, yaitu ketika keberadaan auksin tidak lagi berpengaruh terhadap pembentukan akar. Selama tahap pemanjangan primordia akar, ujung akar tumbuh keluar melalui korteks, dan akhirnya muncul dari epidermis batang.

Hasil penelitian menunjukkan bahwa efektivitas auksin untuk menstimulasi akar pada cangkok jambu bol dari yang paling efektif hingga yang kurang efektif adalah NAA $4000 \mathrm{ppm}>$ IBA $2000 \mathrm{ppm}+\mathrm{NAA}$ $2000 \mathrm{ppm}>\mathrm{NAA} 2000 \mathrm{ppm}>\mathrm{IBA} 1000 \mathrm{ppm}$ + NAA $1000 \mathrm{ppm}>$ IBA 4000 atau 2000 ppm. Pada setek beberapa tanaman, IBA lebih efektif dibandingkan NAA untuk pembentukan akar, misalnya pada setek Pongamia pinnata L. (Kesari et al., 2008), dan setek batang lunak Psidium guajava (Rahman et al., 2004), namun pada setek Abies fraseri efektifitas IBA dalam menstimulasi akar tidak berbeda dengan NAA, walaupun NAA cenderung lebih efektif (Rosier et al., 2004).

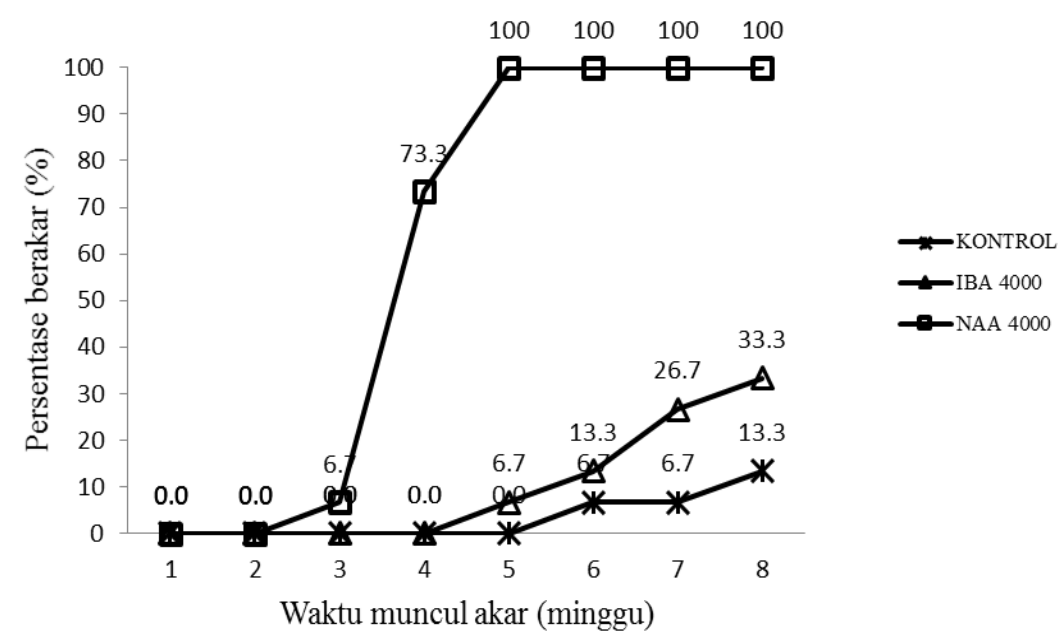

Gambar 5. Perkembangan munculnya akar berdasarkan waktu (minggu) pada cangkok jambu bol tanpa auksin dan dengan 4000 ppm IBA atau NAA. 
Pada setek Cordyline terminalis, kombinasi IBA + NAA menghasilkan bobot segar, bobot kering dan panjang akar yang lebih tinggi dibanding IBA atau NAA (Rahdari et al., 2014). Kombinasi IBA + NAA juga lebih efektif dibanding IBA atau NAA pada setek Ficus carica L. (Reddy et al., 2008). Sejalan dengan hasil penelitian ini, Yusnita $e t$ al. (2018) melaporkan bahwa NAA atau kombinasi IBA + NAA pada konsentrasi total 4000 ppm lebih efektif menstimulasi akar pada setek jambu bol dibanding 4000 ppm IBA. Hal ini membuktikan bahwa efektifitas ZPT tanaman dalam menginduksi perakaran sangat dipengaruhi oleh spesies tanaman, jenis dan konsentrasi ZPT.

\section{KESIMPULAN}

Jambu bol merupakan spesies yang sulit berakar, karena tanpa auksin persentase cangkok berakar hanya $22 \%$ dengan rata-rata jumlah akar primer 4.7. Aplikasi NAA atau kombinasi IBA + NAA dalam bentuk pasta pada cangkok jambu bol semuanya menghasilkan $100 \%$ cangkok berakar, dengan jumlah akar terbanyak (33.3) dihasilkan pada NAA 4000 ppm, diikuti oleh kombinasi IBA 2000 ppm + NAA 2000 ppm (20.8), NAA 2000 ppm (16.1) dan IBA 1000 ppm + NAA 1000 ppm (11.1). Aplikasi IBA 2000 dan 4000 ppm meningkatkan persentase cangkok berakar menjadi $44.4 \%$ dan $55.6 \%$ dan panjang akar, namun tidak berpengaruh terhadap jumlah akar. Aplikasi NAA 4000 ppm juga mempercepat terbentuknya akar hingga tiga minggu lebih awal dibandingkan dengan cangkok tanpa auksin.

\section{DAFTAR PUSTAKA}

Abu-Zahra, T.R., A.N. Al-Shadaideh, S.M. Abubaker, I.M. Qrunfleh. 2013. Influence of auxin concentrations on different ornamental plants rooting. Int. J. Bot. 9(2): 96-99.

Ansari, K. 2013. Effects of different collecting time and different medium on rooting of pomegranate $\mathrm{cv}$. Malas Torsh cuttings. Bull. Environ. Pharmacol. Life Sci. 2(12): 164-168.
Apriani, P., M.R. Suhartanto. 2015. Peningkatan mutu bibit torbangun (Plectranthus amboinicus Spreng.) dengan pemilihan asal stek dan pemberian auksin. J. Hort. Indonesia. 6(2): 109-115.

Benti, T. 2014. Effect of potted media mixtures on rooting ability of stem cuttings of F1 arabica coffee hybrid. Greener J. Plant Breed. Crop Sci. 2(3): 62-66.

Blench, R. 2008. A History of Fruits on the Southeast Asian Mainland. Edited by Toshiki OSADA and Akinori Uesugi. Research Institute for Humanity and Nature, Kyoto, Japan.

Blythe, E.K., J.L. Sibley, K.M. Tilt, J.M. Ruter. 2007. Methods of auxin application in cutting propagation: a review of 70 years of scientific discovery and commercial practice. $\mathrm{J}$. Environ. Hort. 25(3): 166-185.

Chawla, W., K. Mehta, N. Chauhan. 2012. Influence of plant growth regulators on rooting of litchi (Litchi chinensis Sonn.) air layers. Asian J. Hort. 7(1): 160-164.

Denaxa, N.K., S.N. Vemmos, P.A. Roussos, G. Kostelenos. 2011. The effect of IBA and NAA and carbohydrates on rooting capacity of leafy cuttings in three olive cultivars (Olea europaea L.). Acta Hortic. 924: 101-109. DOI: 10.17660/ ActaHortic.2011.924.12.

Dessalegn, Y., Y.N. Reddy. 2003. Effects of different concentrations of auxins on rooting and root characters of air and ground layers of jojoba (Simmondsia chinensis (Link.) C.K. Schneider). Ethiop. J. Sci. 26(2): 155-159.

Dirr, M.A., C.W.H. Junior. 2006. The Reference Manual of Woody Plant Propagation. 2nd. Timber Press. Portland.

Hartmann, H.T., D.E. Kester, F.T. Davies, Jr., R.L. Geneve. 2011. Plant Propagation: 
Principles and Practices $8^{\text {th }}$ ed. Prentice Hall International Inc. New Jersey.

Kesari, V., A. Krishnamachari, L. Rangan. 2008. Effect of auxins on adventitious rooting from stem cuttings of candidate plus tree Pongamia pinnata (L.), a potential biodiesel plant. Trees. DOI 10.1007/s00468-008-0304-x.

Orwa, C., A. Mutua, R. Kindt, R. Jamnadass, S. Anthony. 2009. Agroforestree Database: a tree reference and selection guide version 4.0. World Agroforestry Centre, Syzygium malaccencse (L.) Merr \& Perry. Agroforestry Database 4.0. http://www.worldagroforestry.org/ treedb2/speciesprofile.php?Spid=18099 [2 November 2016].

Khajehpour, G., V. Jam'eizadeh, N. Khajehpour. 2014. Effect of different concentrations of IBA (Indolebutyric Acid) hormone and cutting season on the rooting of the cuttings of olive (Olea europea var. Manzanilla). Int. J. Adv. Biom. Res. 12(2): 2920-2924.

Khorsheduzzaman, A.K.M., M.Z. Alam, M.M. Rahman, M.M.A. Khaleque, H.M.M Ismail. 2010. Biochemical basis of resistance in eggplant (Solanum melongena L.) to Leucinodes and their correlation with shoot and fruit infestation. Bangladesh J. Agric. Res. 35: 149-155.

Paul, R., C. Aditi. 2009. IBA and NAA of $1000 \mathrm{ppm}$ induce more improved rooting characters in air-layers of waterapple (Syzygium javanica L.). Bulgarian J. Agric. Sci. 15(2): 123-128.

Rahdari, P., M. Khosroabadi, K. Delfani. 2014. Effect of different concentration of plant hormones (IBA and NAA) on rooting and growth factors in root and stem cuttings of Cordyline terminalis. J. Med. Bioeng. 3(3): 190-194.

Rahman, N., T.G. Nabi, T. Jan. 2004. Effect of different growth regulators and type of cuttings on rooting of guava (Psidium guajava L.). Quarterly Sci. Vision. 9(12): $1-5$.

Rahmania, R. Kurniawati, A. 2014. Penentuan ukuran stek kumis kucing (Orthosiphon aristatus Bl. Miq.) dan dosis pupuk kandang pada cara tanam langsung. J. Hort. Indonesia 5(3):189-202.

Rebin, 2013. Teknik perbanyakan jambu air Citra melalui stek cabang. Iptek Hortikultura 9: 6-10.

Reddy, K.V. Rajeswara, C. Pulla Reddy, P.V. Goud. 2008. Effect of auxins on the rooting of fig (Ficus carica L.) hardwood and semi hardwood cuttings. Indian J. Agric. Res. 41(1): 75-78.

Rosier, C.L., J. Frampton, B. Goldfarb, F.A. Blazich, F.C. Wise. 2004. Growth stage, auxin type, and concentrartions influence rooting of stem cuttings of fraser fir. HortSci. 39(6): 1397-1402.

Rout, G.R. 2006. Effect of auxins on adventitious root development from single node cuttings of Camelia sinensis (L.) Kuntze and associated biochemical changes. Plant Growth Reg. 48: 111117.

Ryadin, A.R, S.L. Ranamukaarachchi, P. Soni, R. P. Shrestha. 2014. Vegetative propagation of five local cultivars of malay apple (Syzygium malaccense spp.) in Ternate Island. Intern. J. Advanced Sci. Engineer. Inform.Tech. 4(2): 35-39.

Santoso, B.B. 2014. Seedling growth from stem cutting with different physiological ages of Jatropha curcas L. of West Nusa Tenggara genotypes. International J. App. Sci. Tech. 4(6): 510.

Sardoei, A.S. 2014. Effect of different media of cuttings on rooting of guava (Psidium guajava L.). Euro. J. Exp. Bio. 4(2): 88-92.

Shadparvar, V., M.A. Torkashvand, A.H. Alamshiri. 2011. Effect of IBA and soil 
mixture on rooting of Hibiscus rosasinensis. Euro. J. Exp. Bio. 1(4): 142146.

Singh, K.K., J.M.S. Rawat., Y.K. Tomar. 2011. Influence of IBA on rooting of Torch Glory Bougainvillea glabra during winter season. J. Hort. Sci. Ornament. Plants. 3(2): 162-165.

Whistler, W.A., C.R. Elevitch. 2006. Syzygium malaccense (Malay apple). Species profiles for Pacific island agroforestry. www.traditionaltree.org. [2 November 2016].

Yan, Y. H., J.L. Li., X.Q. Zhang, W.Y., Yang, Y. Wan, Y.M., Ma, Y.Q. Zhu, Y. Peng, L.K. Huang. 2014. Effect of naphthalene acetic acid on adventitious root development and associated physiological changes in stem cutting of Hemarthria compressa. 9(3): 1-6. PLOS ONE. www.plosone.org.

Yusnita, Jamaludin, Agustiansyah, D. Hapsoro. 2018. Effects of IBA, NAA and their combination on rooting and shoot sprouting of Malay apple (Syzygium malaccense (L.) Merr. \& Perry) stem cuttings. Agrivita J. Agric. Sci. 40(1): 80-90.

Zaczek, J.J., K.C. Steiner, C.W. Heuser, Jr., W. Tzilkowski. 2006. Effects of serial grafting, ontogeny and genotype on rooting of Quercus rubra cuttings. Can. J. Forest Res. 36(1): 123-131. 